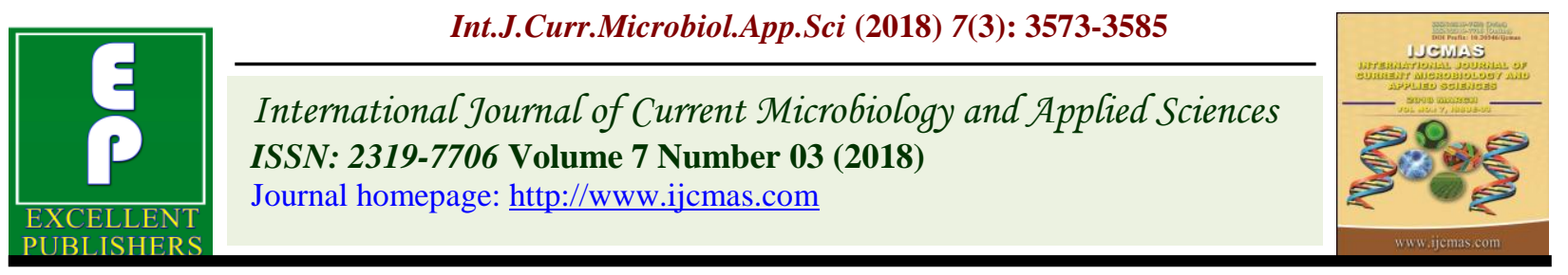

Original Research Article

https://doi.org/10.20546/ijcmas.2018.703.411

\title{
In vitro Interactions of Fungal Isolates obtained from Selected Soil Samples in Ado-Ekiti Metropolis and their Tolerance to Selected Fungicide and Heavy Metals
}

\author{
E.A. Ekundayo ${ }^{1}$, F.C. Akharaiyi ${ }^{1}$, F.O. Ekundayo ${ }^{2}$, E. Prebor ${ }^{1}$, \\ O.T. Ogunmefun ${ }^{1}$ and Y. Oluwafemi ${ }^{3}$ \\ ${ }^{1}$ Department of Biological Sciences, Afe Babalola University, Ado-Ekiti, Nigeria \\ ${ }^{2}$ Department of Microbiology, Federal University of Technology, Akure, Nigeria \\ ${ }^{3}$ Department of Biological Sciences, University of Medical Sciences, Ondo, Nigeria \\ *Corresponding author
}

\section{A B S T R A C T}

\begin{tabular}{|c|}
\hline Keywords \\
\hline $\begin{array}{l}\text { Fungi, } \\
\text { interactions, } \\
\text { Heavy metals, } \\
\text { Fungicide, } \\
\text { Rhizosphere. }\end{array}$ \\
\hline Article Info \\
\hline $\begin{array}{l}\text { Accepted: } \\
28 \text { February } 2018 \\
\text { Available Online: } \\
10 \text { March } 2018\end{array}$ \\
\hline
\end{tabular}

Fungi were isolated from five different rhizosphere of some plants obtained from Afe Babalola University, Ado-Ekiti farm and Federal Polytechnic Ado-Ekiti on Potato Dextrose Agar (PDA) incubated at $27^{\circ} \mathrm{C}$. The isolates were Trichoderma viride, Aspergillus fischeria, A. terreus, A. fumigatus, A. clavatus, Articulospora inflata, Penicillium italicum and Mucor mucedo. The interaction that existed between the fungal isolates was determined and it was observed that $T$. viride suppressed the growth of other fungal isolates. Effects of a fungicide; Ridomil gold at four different concentrations on the rate of growth of the isolates were determined. Trichoderma viride, P. italicum and A. fischeria were able to grow on different concentrations of Ridomil gold. Effeet of heavy metals; zinc and lead at different concentration on the growth rate of isolates was determined. This study showed that Trichoderma viride was mostly resistant to the heavy metals and the lower the concentration, the higher the rate of growth of the fungi.

\section{Introduction}

Soil is a rich habitat containing different groups of microorganisms (Mueller and Bills, 2004) which help in the degradation and synthesis of organic compounds (Iram et al., 2009). Soil microorganisms also play major roles in evaluation of soil conditions and stimulating plant growth (Kiran et al., 1999). Nature has provided planet earth with a variety of beneficial organisms. Microorganisms are beneficial in increasing involved in several biochemical transformation and mineralization activities in soils (Ganae et al., 2010).

Fungi constitute a group of microorganisms that are widely distributed in environment especially in soil and play an important role as major decomposers in the soil ecosystem (Boer et al., 2005; Seth et al., 2016). Also, their presence in soil strongly influences ecosystem structure and functioning and thus 
plays key roles in many ecological services (Orgiazzi et al., 2012).

Environmental pollution with fungicide as well as heavy metals is a global concern (Dular et al., 2015). Accumulation of these compounds leads to undesirable changes in the biosphere (Djukic and Mandic, 2000). Exposure to toxic heavy metals is a severe public health concern due to the harmful effects which may cause illness. The ingestion of contaminated food and water through eating and drinking and inhalation of polluted air results heavy metal poisoning (Oghenekaro et al., 2008) or may lead to the development of chronic and cardiovascular diseases (Alissa and Ferns, 2011). Conventional techniques commonly adopted in removal of heavy metals from contaminated soils include both chemical and physical methods. Also, microorganisms are capable of converting these organic compounds to harmless products. Biological approach has the great potential that contributes for the achievement of this goal. Biosorption is proven to be quite effective for the removal of metal ions from contaminated solution in a low cost and environment friendly manner (Volesky, 1990).

This present study therefore evaluates the interactions that exist among fungal isolates obtained from soil samples and the effects of Ridomil gold (fungicide) and heavy metals $(\mathrm{Zn}$ and $\mathrm{Pb})$ on the fungal isolates.

\section{Materials and Methods}

\section{Collection of samples}

Soil samples were collected from five different rhizosphere from Afe Babalola University (ABUAD) farm as well as The Federal Polytechnic, Ado-Ekiti, Ekiti State using soil auger. All samples were collected in small sterile nylon and properly labeled.
Fungicide, Ridomil gold as well as heavy metals, zinc and lead were collected from the Department of Biological Sciences and Chemistry laboratory, ABUAD respectively.

\section{Isolation of fungi from the samples}

Fivefold serial dilution was made from all samples. An aliquot $(0.1 \mathrm{ml})$ of fifth dilution was plated in duplicates on sterile potato dextrose agar with antibiotics and incubated at $27^{\circ} \mathrm{C}$ for 3 to 5 days using pour plate method. The colonies were counted on the fourth day. Colonies were selected from each plate and purified by subculturing into PDA plates. Subculturing was done until pure fungal isolates were obtained. The fungal isolates were identified according to Singh et al., (1991).

\section{Growth interaction of the fungal isolates}

Potato dextrose agar was prepared and autoclaved at $121^{\circ} \mathrm{C}$ for 15 minutes. Using a sterile cork borer $(7 \mathrm{~mm})$, the fungal isolates were placed in opposite direction on potato dextrose agar plates and incubated at $27^{\circ} \mathrm{C}$. The growth rate was measured at day 2,4 and 6.

\section{Effect of Ridomil gold on the growth of the fungal isolates}

Sterilized potato dextrose agar was prepared and amended with different concentrations $(1.8,0.8,0.5,0.05 \mathrm{~g} / \mathrm{L})$ of the fungicide after autoclaving. Fungal plug $(7 \mathrm{~mm})$ was then placed on the petri plates and incubated for at $27^{\circ} \mathrm{C}$ for 3 to 5 days.

\section{Effect of heavy metals on the fungal isolates}

Different concentrations of zinc and lead (1, 5, 10, $20 \mathrm{ppm}$ ) were added to sterile PDA plates. A sterilized cork borer was used to 
transfer mycelia mat of the fungus on to the plates and was incubated at $27^{\circ} \mathrm{C}$ for 3 to 5 days. Fungal cultures without the heavy metals served as control (Volesky, 1990).

\section{Results and Discussion}

Fungal species obtained from the soil samples

Eight fungi were isolated from the different soil samples. The fungi were identified as Trichoderma viride, Aspergillus fischeria, A. clavatus, A. fumigatus, Articulospora inflata, Penicillium italicum, Aspergillus terreus and Mucor mucedo based on microscopic and cultural examinations

\section{Interaction between fungal isolates}

Some of the fungi grew mutually when cocultured while others inhibited the growth of the fungi cultured with it. For example, Aspergillus fischeria and A. clavatus grew mutually. The growth of A. fumigatus was inhibited by Trichoderma viride with growth measured as $25 \mathrm{~mm}$ and $47 \mathrm{~mm}$ respectively at day 6 (Figure 1).

\section{Effects of Ridomil gold on the growth of the fungal isolates}

Trichoderma viride, Aspergillus fischeria and Penicillium italicum were able to grow on fungicide at different concentrations $(0.05 \%$, $0.5 \%, 0.8 \%$ ) while others were susceptible to the fungicide. However, at $1.8 \%$ concentration of fungicide, no growth was observed (Table 1).

\section{Effects of heavy metals on the growth of the fungal isolates}

The selected heavy metals had varying effects on the fungal isolates as shown in figures 2-9. Generally, Trichoderma viride was most resistant to zinc and lead as growth was observed at 5, 10 and 20 ppm of zinc and lead respectively except at $1 \mathrm{ppm}$ of lead. The most susceptible isolates to the heavy metals were Articulospora inflata and Mucor mucedo which showed no growth at all concentrations of the heavy metals except at 10 and 20 ppm of lead with mycelial growth measured as 5 and $16 \mathrm{~mm}$ for Mucor mucedo. Figures 10 to 13 show the comparative effects of the selected heavy metals on fungal isolates. ). Mucor mucedo and Articulospora inflata did not show any growth at all concentrations of zinc as shown in figures 10 and 11. Mucor mucedo was most susceptible to lead followed by Penicillium italicum, $A$. terreus and $A$. fischeria at day 3 (Figure 12) while no growth was seen for M. mucedo at 1, 5, 10ppm for lead at day 5 (Figure 13).

Soil microflora plays a pivota role in evaluation of soil conditions and in stimulating plant and growth (Kiran et al., 1999). Fungi are fundamental for soil ecosystem functioning especially in forest and agricultural soils, they play a key role in many essential processes such as organic matter decomposition and nutrient cycling processes (Barlocher, 2005; Shearer et al., 2007). Some of the fungal isolates obtained from this study have been isolated from soil sample elsewhere which is a testament to the ubiquity of fungi (Reddy et al., 2014; Seth et al., 2016). Jahangeer et al., (2005) also isolated Aspergillus, Alternaria, Trichoderma Penicillium and Rhizopus sp. from the soil samples. These findings were also similar with Luis Henerique et al., (2010) who isolated A. niger, A. flavus, and Mucor from the soil samples. The fungal isolates obtained from this study have a lot of biotechnological applications. For example, Trichoderma and Aspergillus are cellulase producers, and their crude enzymes are commercially available for agricultural use (Domigues et al., 2000; Gaddeya et al., 2012; Lynd et al., 2002, Li et al., 2010). 
Among the fungal isolates that were cocultured, Aspergillus fischeria was suppressed by Trichoderma viride while Penicillium italicum and Aspergillus terreus grew mutually. Species of Trichoderma are widely recognized for their biocontrol abilities (Mishra et al., 2016).

Fungicide resistance is a stable, inheritable adjustment by a fungus to a fungicide, resulting in reduced sensitivity of the fungus to the fungicide. Resistant isolates are less affected or not inhibited at all by application of a fungicide (Ma and Michailides, 2005). Ruocco et al., (2009) explained that the ability of Trichoderma to withstand relatively high concentrations of a variety of synthetic and natural toxic compounds depends on efficient cell detoxification mechanisms supported by a complex system of membrane pumps. The genome of Trichoderma includes ABC transporters (ATP- binding cassette (ABC) transporters), which may provide a mechanism of protection against cytotoxic drugs and xenobiotic agents. Ezzi and Lynch (2005), Tang et al., (2009) and Zhou et al., (2007) have shown that Trichoderma has the capability of degrading xenobiotic compounds. Also, Goldman et al., (1993) as well as Mukherjee et al., (1999) successfully obtained T. viride and T. pseudokoningii strains that could tolerate chemical fungicides. The resistance mechanism of some fungi to chemical fungicides may be due to mutations, which reduce their susceptibility to the fungicides as well as decrease their efficacy (Goldman et al., 1993; Yan and Dickman, 1996; Deyle et al., 1997; Yamamoto and Baird, 1999).

Table.1 Mycelial growth of fungal isolates in the presence of the fungicide, Ridomil gold

\begin{tabular}{|c|c|c|c|c|}
\hline \multirow[t]{2}{*}{ Fungal isolates } & \multicolumn{4}{|c|}{ Concentrations of fungicide $(\mathrm{g} / \mathrm{L})$} \\
\hline & 0.05 & 0.5 & 0.8 & 1.8 \\
\hline Penicillium italicum & + & + & + & - \\
\hline Trichoderma viride & + & + & + & - \\
\hline Aspergillus fischeria & + & - & - & - \\
\hline A. fumigatus & - & - & - & - \\
\hline A. clavatus & - & - & - & - \\
\hline A. terreus & - & - & - & - \\
\hline Mucor mucedo & - & - & - & - \\
\hline Articulospora inflata & - & - & - & - \\
\hline
\end{tabular}

Key:

+ : Mycelial growth

-: No growth was observed 
Fig.1 Growth rate of different fungal isolates from ABUAD and Federal Polytechnic, Ado-Ekiti

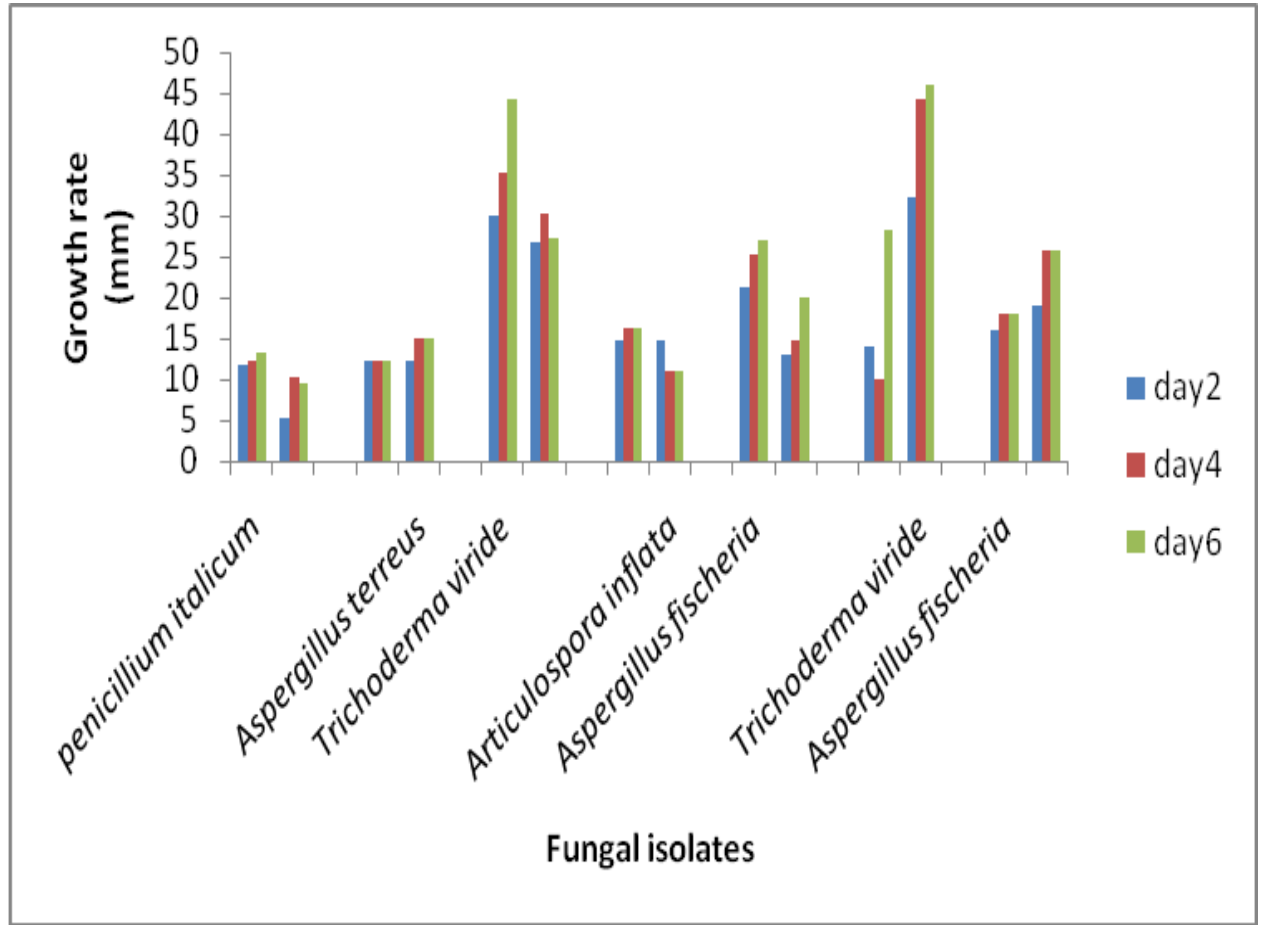

Fig.2 Effect of zinc (20ppm) on the mycelial growth of fungal isolates obtained from ABUAD and Federal Polytechnic, Ado-Ekiti

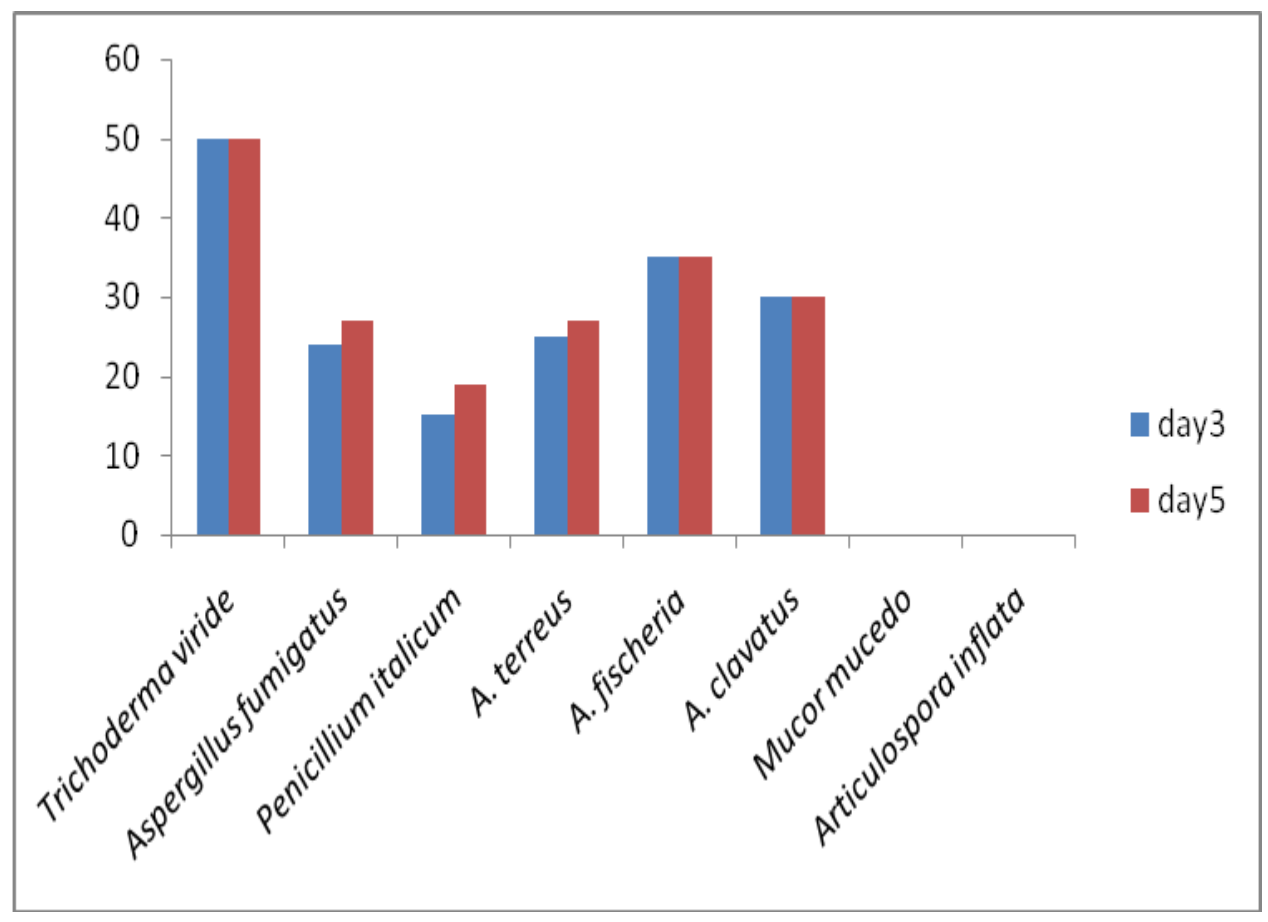


Fig.3 Effect of zinc (10ppm) on the mycelial growth of fungal isolates obtained from ABUAD and Federal Polytechnic, Ado-Ekiti

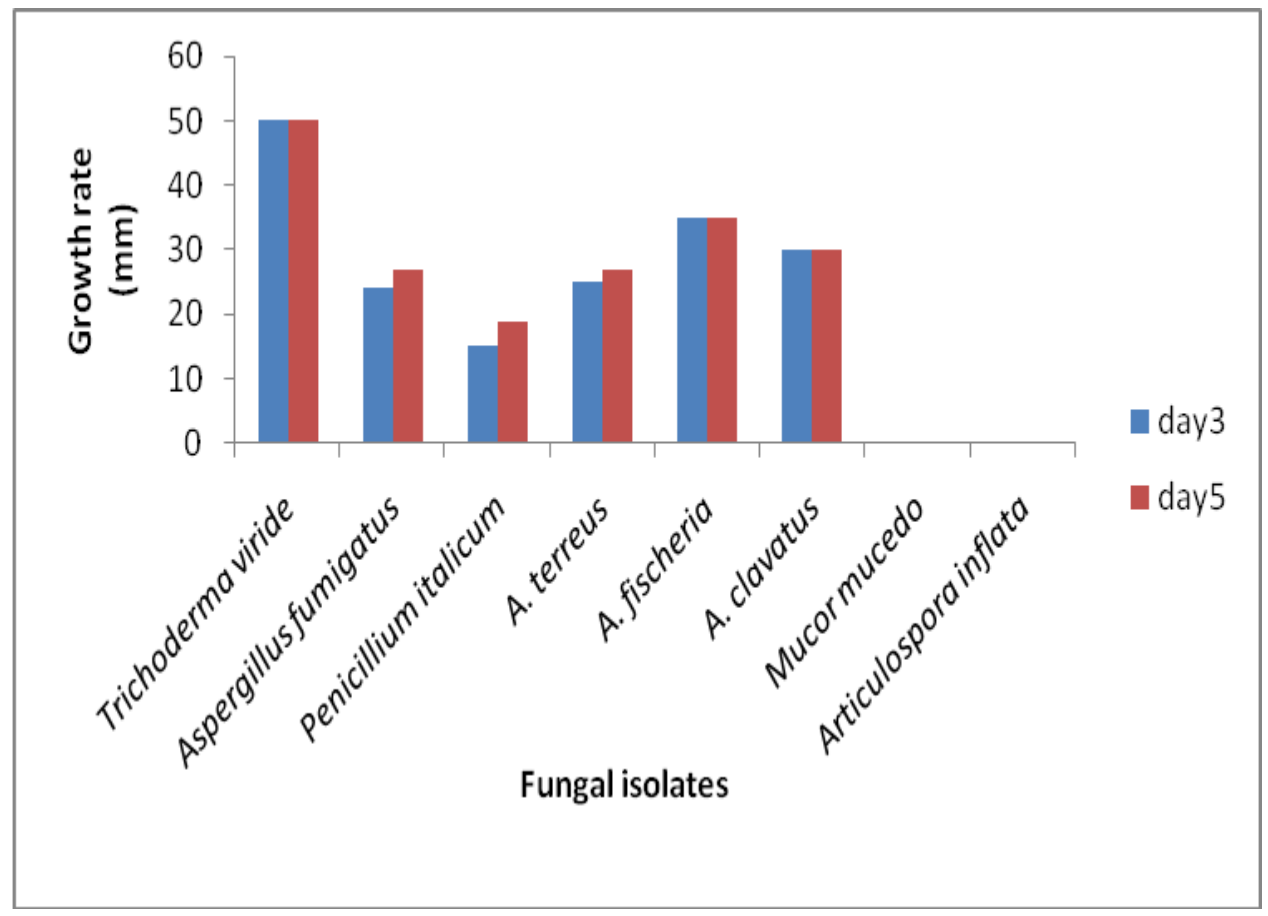

Fig.4 Effect of zinc (5ppm) on the mycelial growth of fungal isolates obtained from ABUAD and Federal Polytechnic, Ado-Ekiti

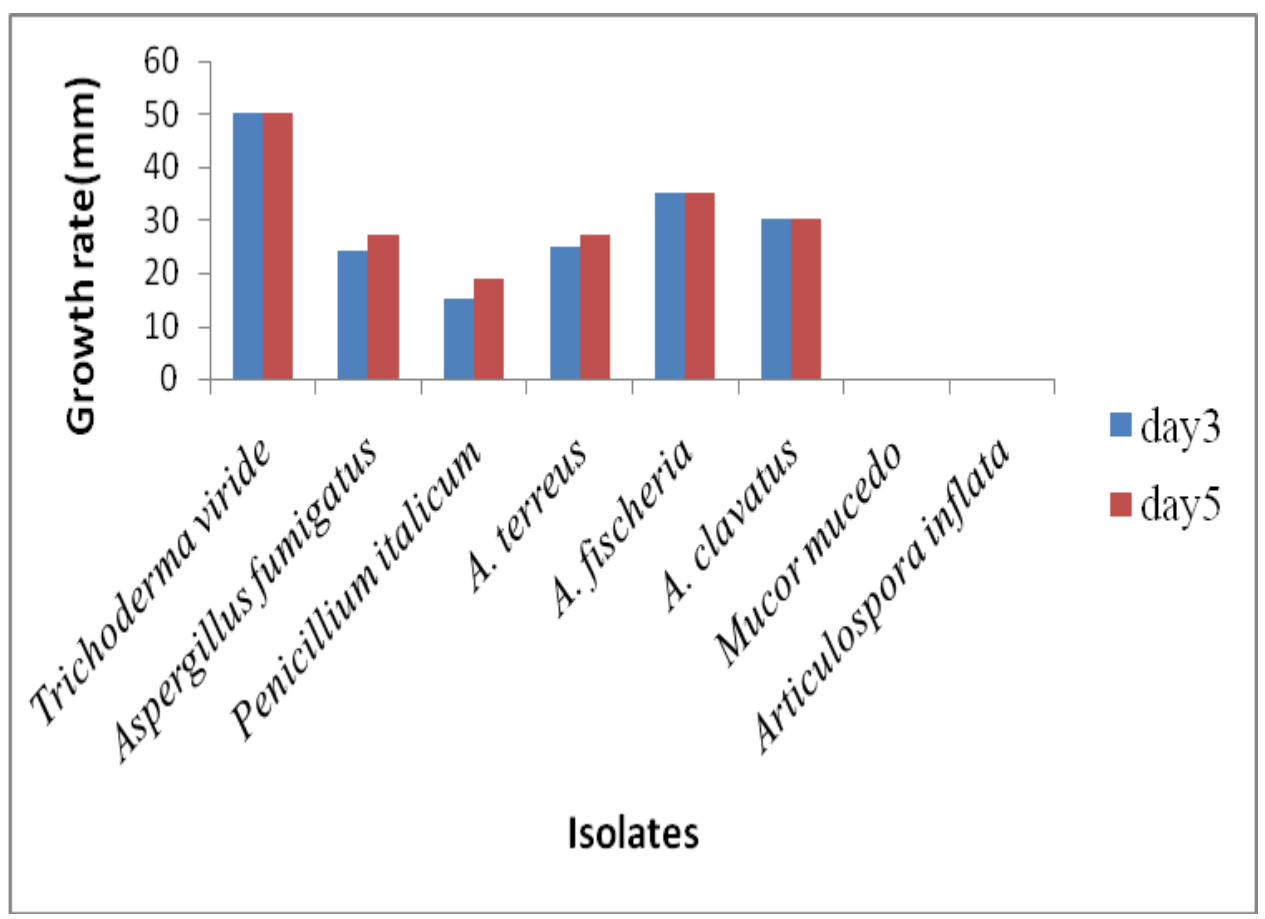


Fig.5 Effect of zinc (1ppm) on the mycelial growth of fungal isolates obtained from ABUAD and Federal Polytechnic, Ado-Ekiti

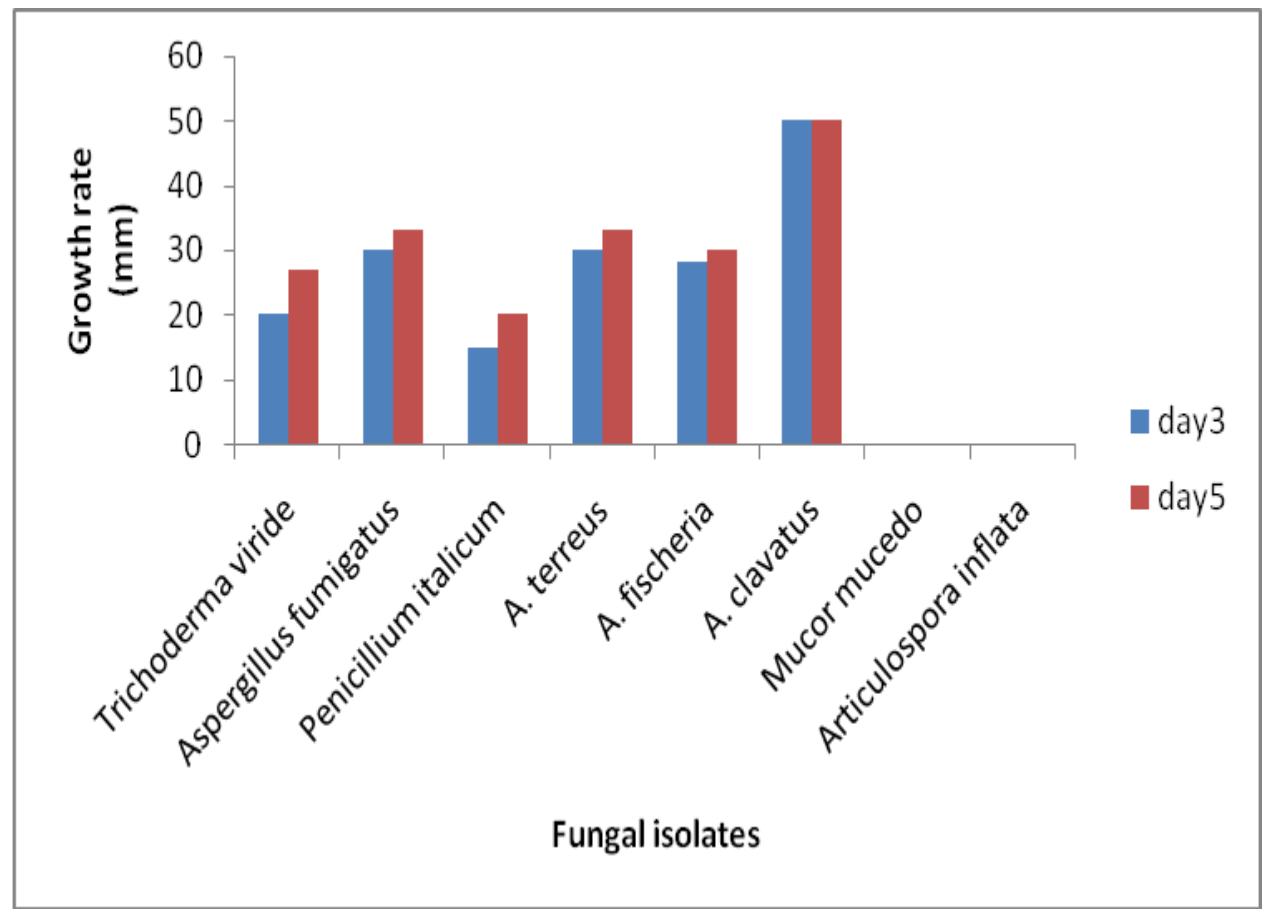

Fig.6 Effects of lead (20ppm) on the mycelial growth of fungal isolates obtained from ABUAD and federal polytechnic, Ado-Ekiti

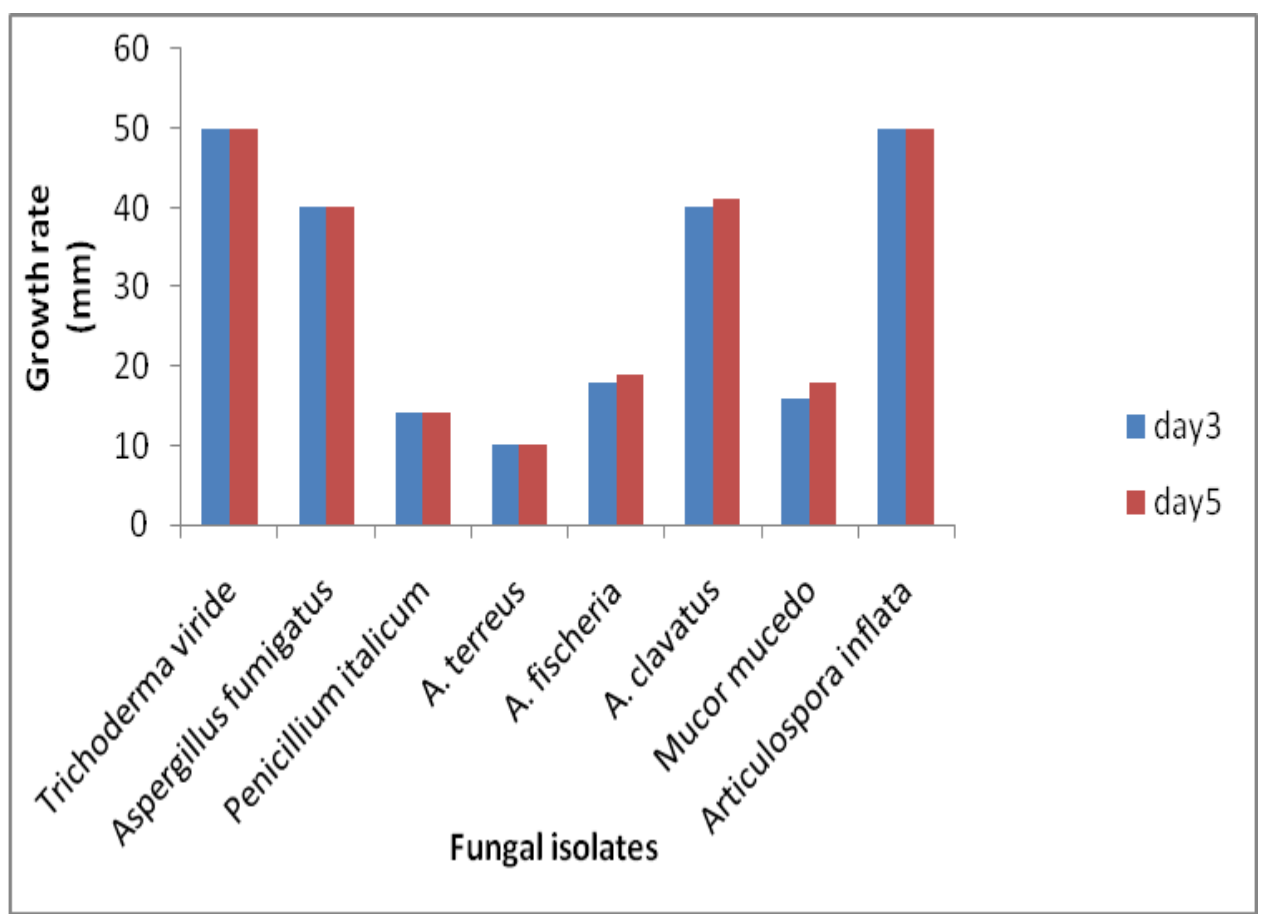


Fig.7 Effects of lead (10ppm ) on the mycelial growth of fungal isolates obtained from ABUAD and Federal Polytechnic, Ado-Ekiti

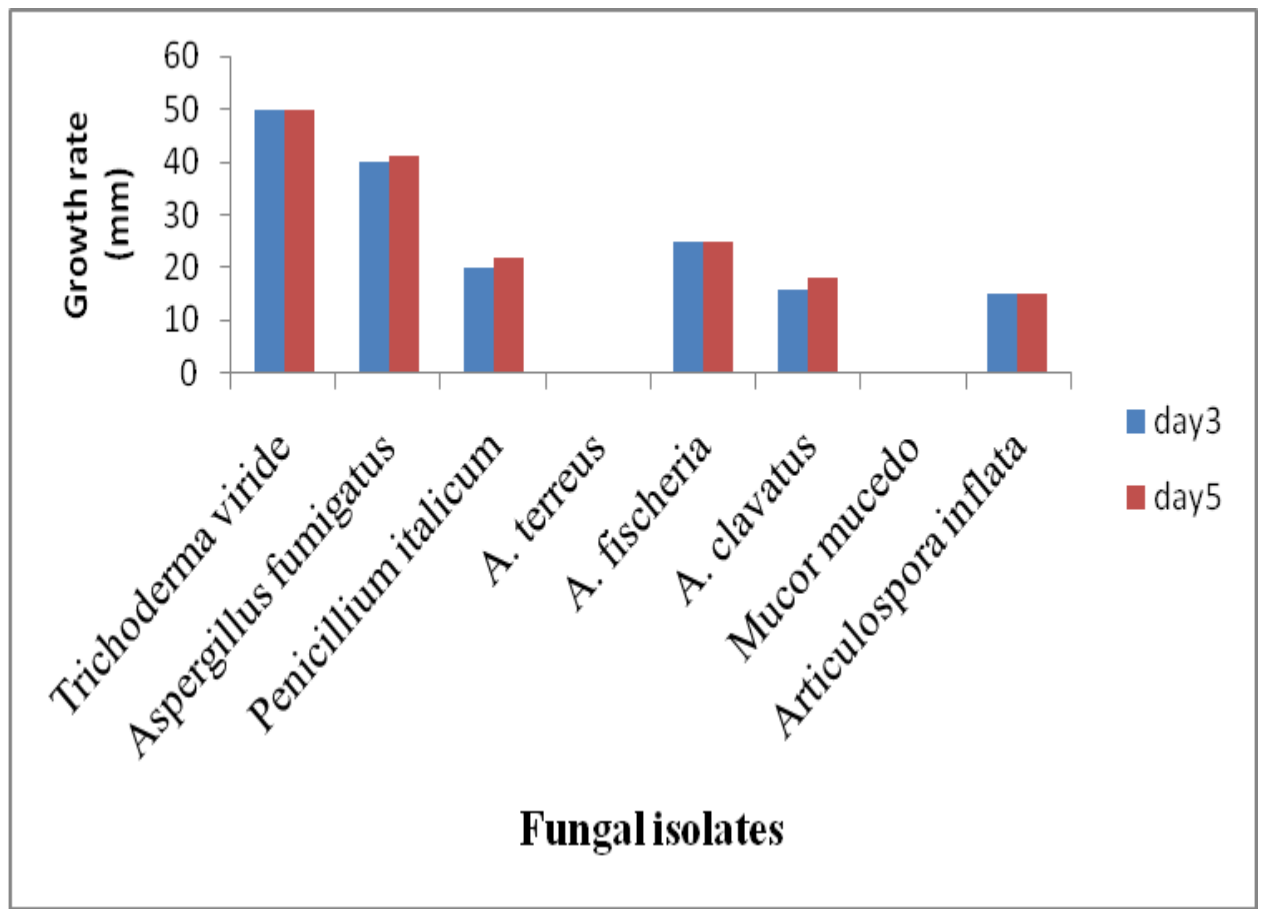

Fig.8 Effect of lead (5ppm) on the mycelial growth of fungal isolates obtained from ABUAD and Federal Polytechnic, Ado-Ekiti

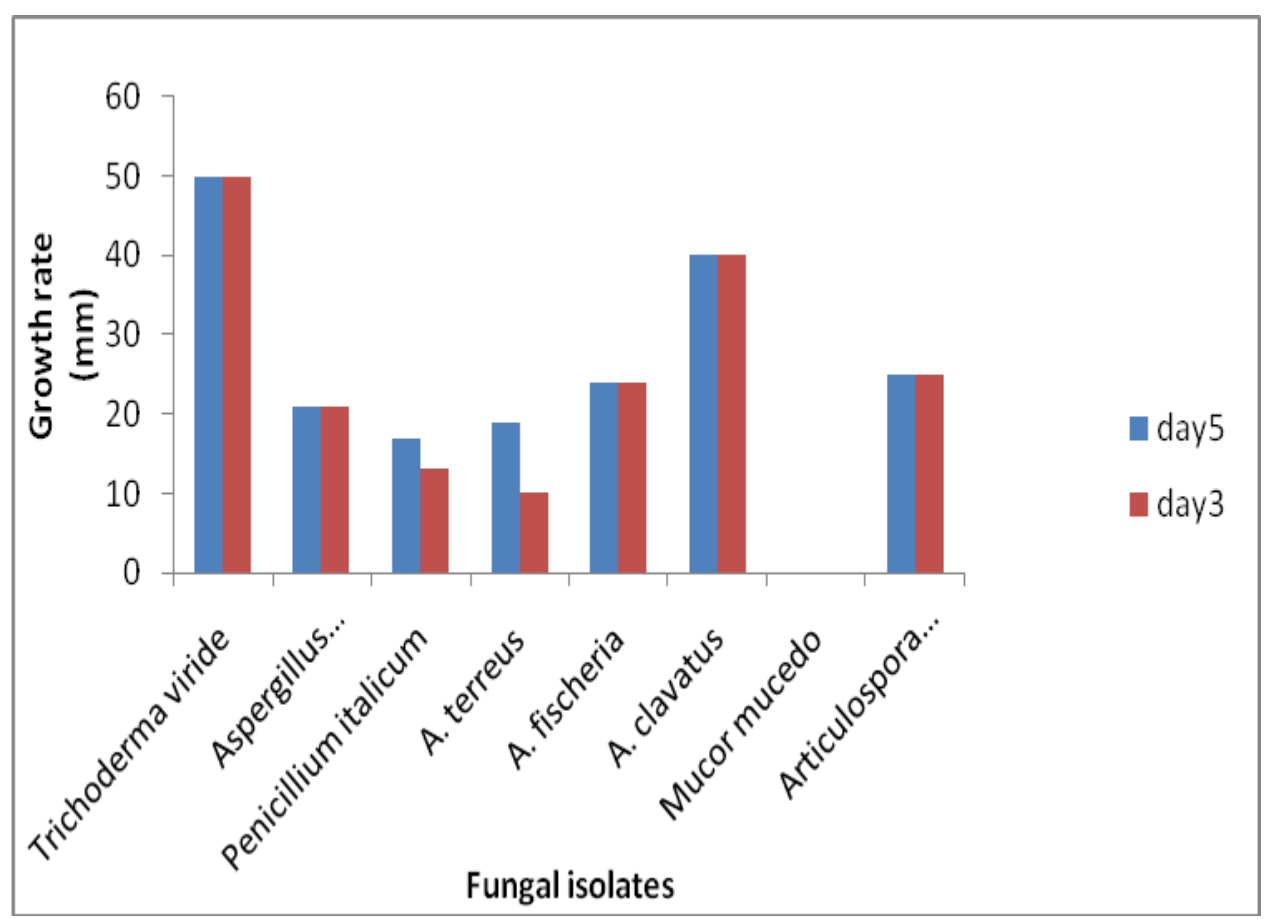


Fig.9 Effect of lead (1ppm) on the mycelial growth of fungal isolates obtained from ABUAD and Federal Polytechnic, Ado-Ekiti

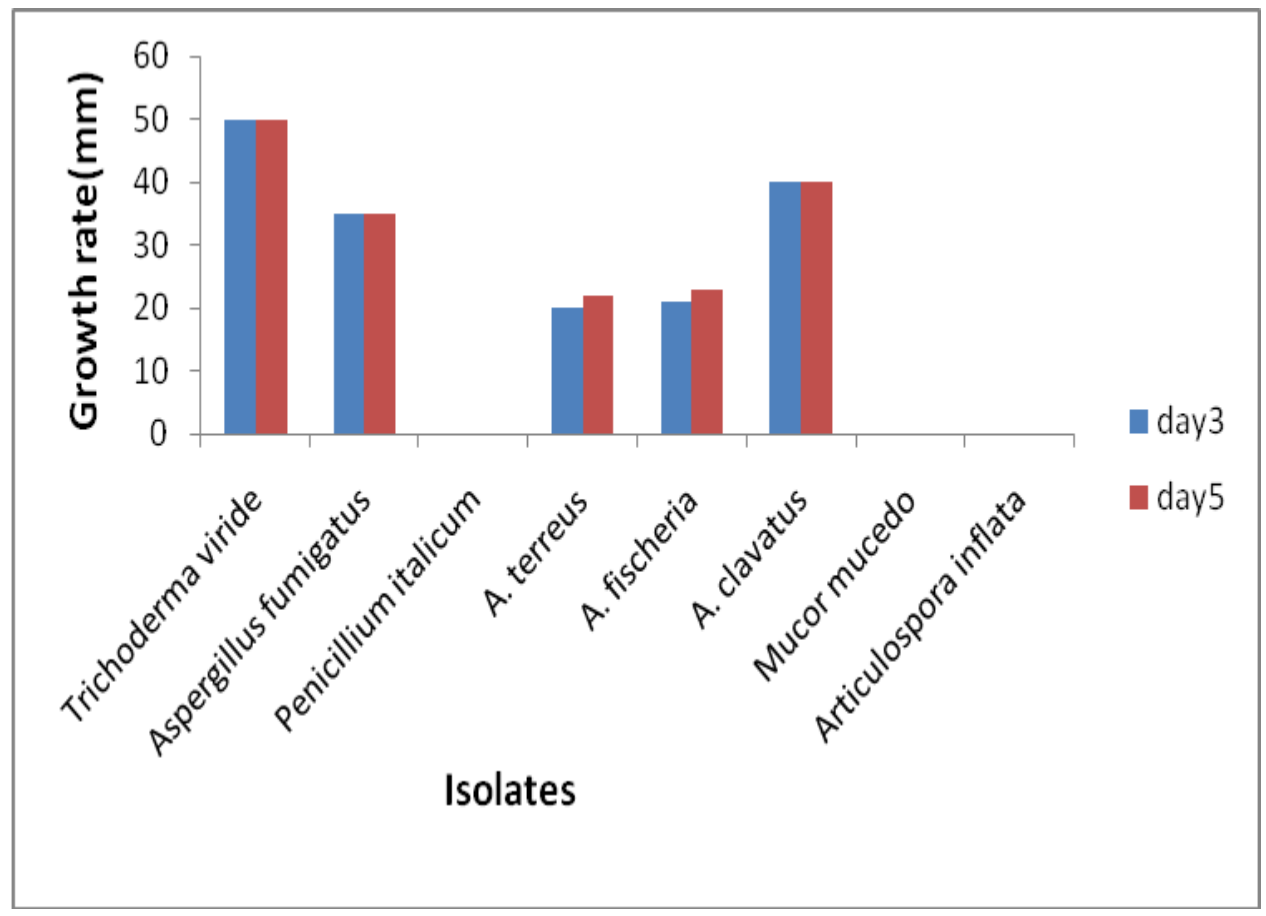

Fig.10 Comparative effect of zinc at different concentrations at day 3 on the mycelial growth of fungal isolates obtained from ABUAD and Federal Polytechnic, Ado-Ekiti

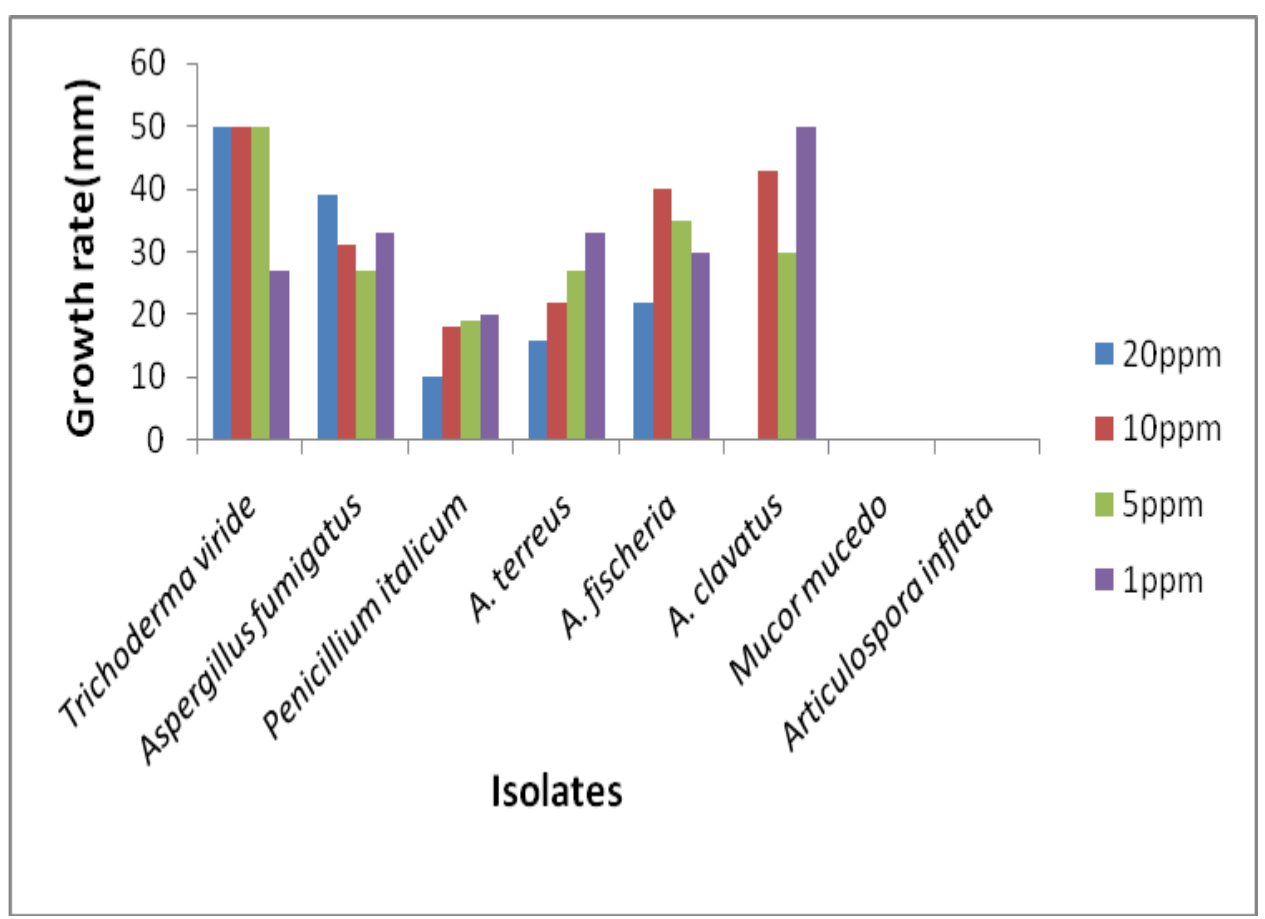


Fig.11 Comparative effect of zinc at different concentrations at day 5 on the mycelial growth of fungal isolates obtained from ABUAD and Federal Polytechnic, Ado-Ekiti

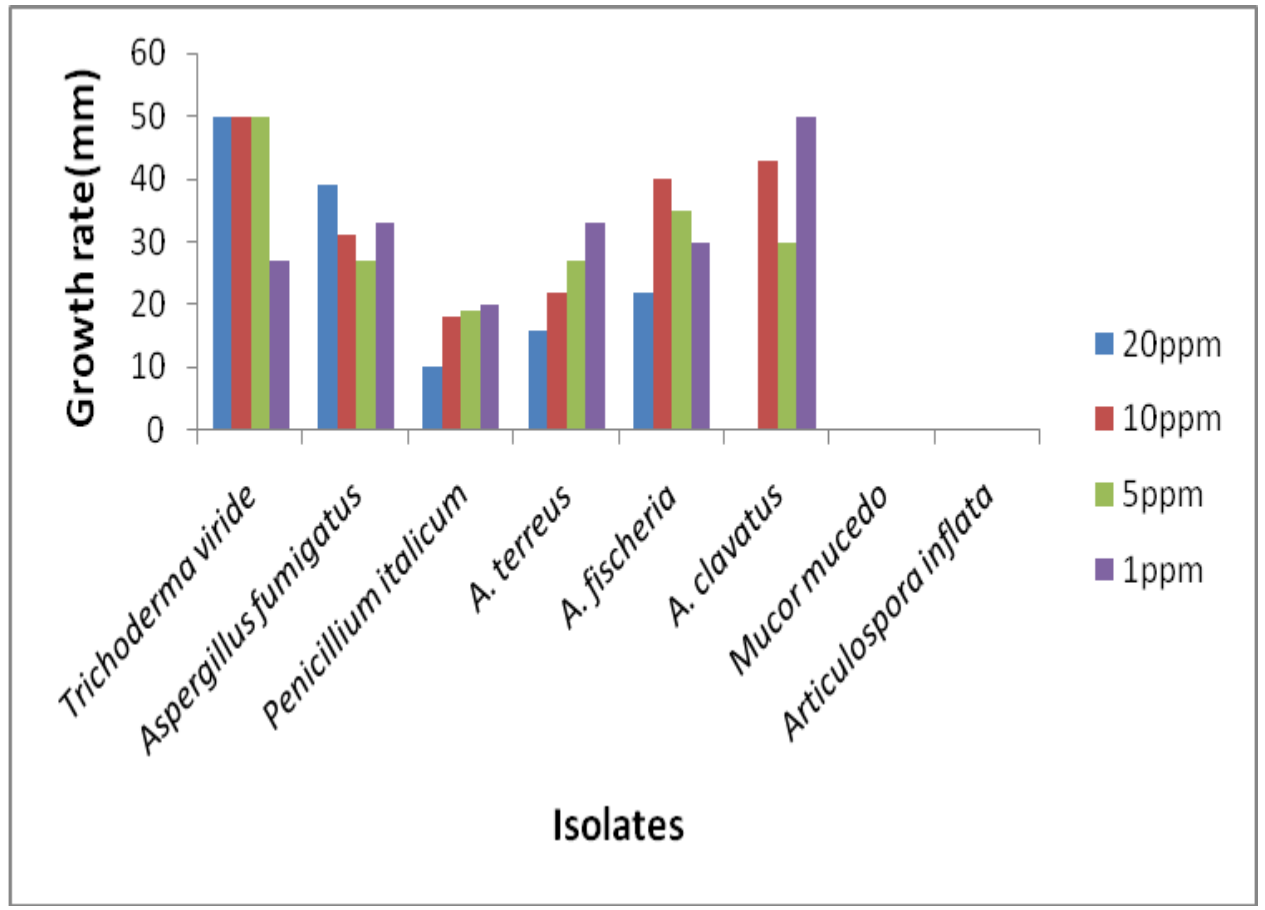

Fig.12 Comparative effects of lead at different concentrations at day 3 on the mycelial growth of fungal isolates obtained from ABUAD and Federal Polytechnic, Ado-Ekiti

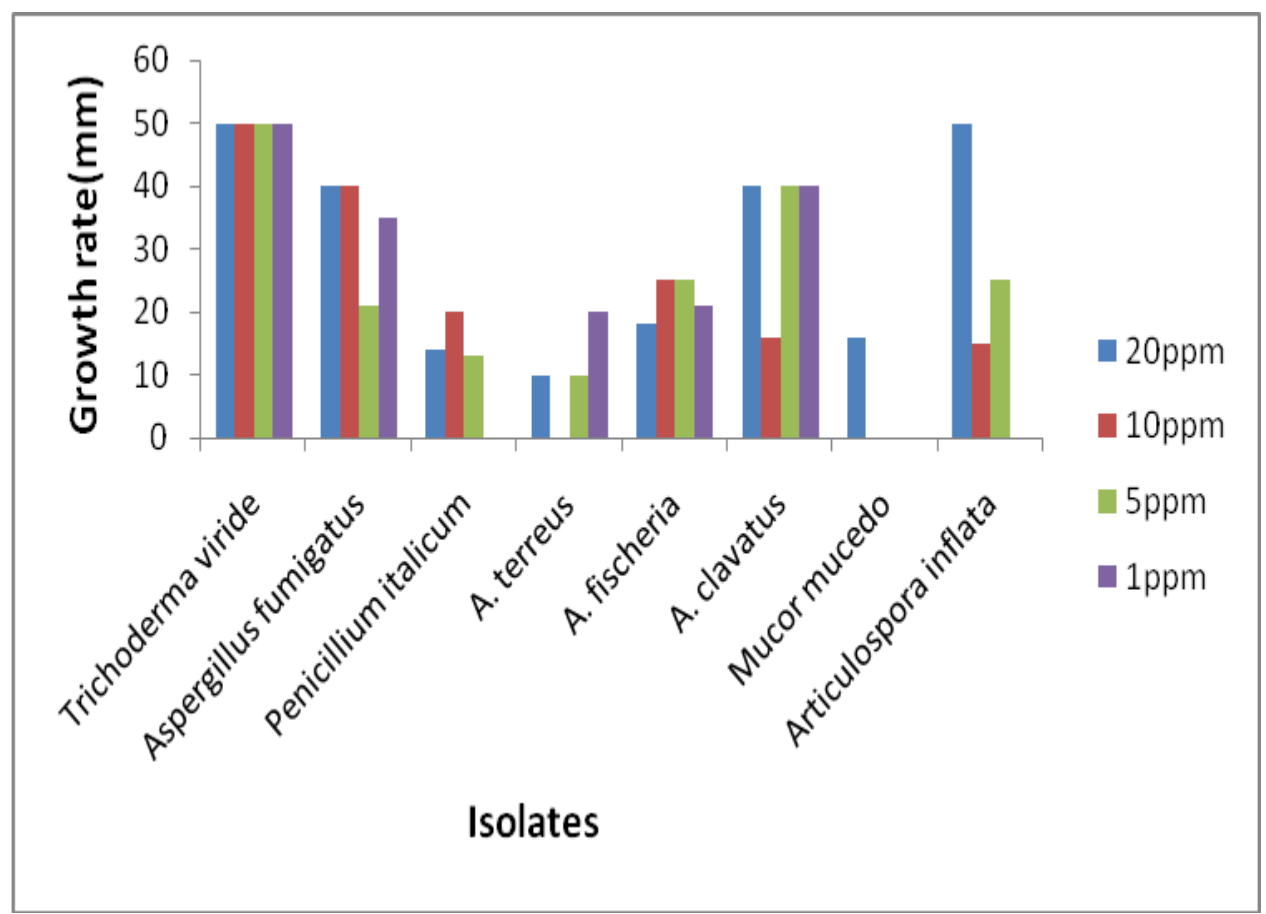


Fig.13 Comparative effect of lead at different concentrations at day 5 on the mycelial growth of fungal isolates obtained from ABUAD and Federal Polytechnic, Ado-Ekiti

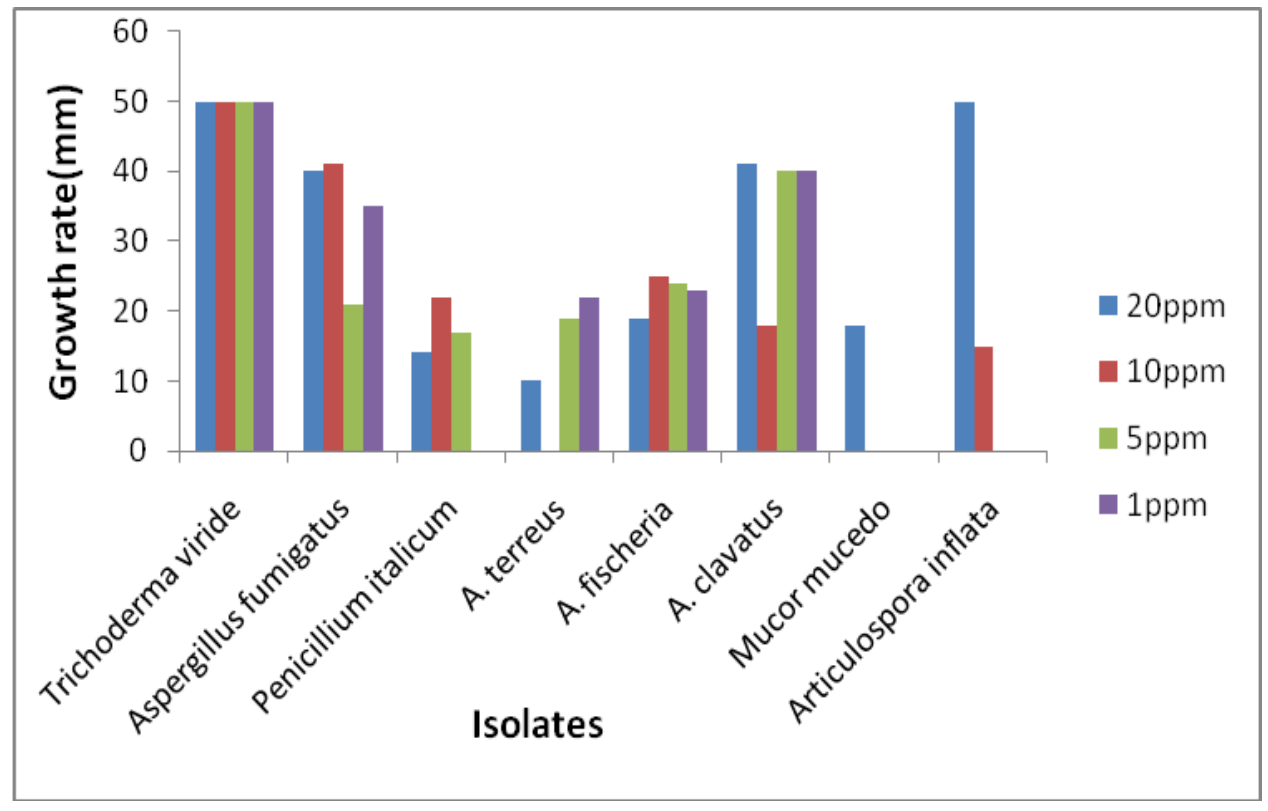

Heavy metals are environmental contaminants are not a new phenomenon (Kredics et al., 2003; Dulay et al., 2015). They are essential part of all living organisms and are present in trace amount in soil naturally. The introduction of heavy metal compounds into the environment generally induces morphological and physiological changes in the microbial communities (Vadkertiova and Slavikova, 2006). In naturally polluted environments, the microbe's response to heavy metals toxicity depends on the concentration and the availability of metals. In this present study, the growth rate of Trichoderma viride on 5, 10 and 20 ppm of zinc and lead was high which means that the fungus had the capability of cometabolizing the metals. Zúñiga-Silva et al., (2015) reported that Aspergillus japonicus and Trichoderma atroviride were the most tolerant isolates to all tested metals. This suggests that these isolates are promising candidates for further study with regard to mycoremediation and biosorption of heavy metal-polluted soils. Previous study by Mishra et al., (2016) has shown that $T$. hiarzianum KSNM (T103) to tolerate biotic (root pathogens) and abiotic stresses [high salt (100-1000 mM); heavy metal (chromium, nickel and zinc: 1-10 mM); pesticides: malathion (100-600 ppm), carbofuran (100-600 ppb)], along with its ability to support plant growth.

\section{Conclusion and recommendation}

This study highlights the outcome of the interaction of the fungal isolates and it has can be deduced that fungal isolates that grew mutually can be used together for biocontrol and bioremediation instead of using single organism. This study highlights since Trichordema viride was most tolerant to zinc and lead at different concentrations and it can therefore be used for biosorption of these heavy metals.

\section{References}

Alissa, E.M., Fern, G.A. 2011. Heavy Metal Poisoning and Cardiovascular Disease. $J$. Toxicol., 01/2011; 2011: 870125. DOI: 10.1155/2011/870125. Source: PubMed.

Bärlocher, F. 2005. Freshwater fungal communities. In: Deighton J, Oudemans P, White $\mathrm{J}$ (Eds.), The fungal community: 
Its Organization and Role in the Ecosystem, 3rd ed, Taylor and Francis, CRC Press, Boca Raton, Florida, pp. 3959.

Boer, W., Folman, L.B., Summerbell, R.C. and Boddy, L. 2005. Living in a fungal world: impact of fungi on soil bacterial niche development. FEMS Microbiol. Rev., 29(4): 795-811.

Christensen, M. 1989. A view of fungal ecology. Mycologia, 81: 1-19.

Deyle, C., Laigret, F. and Corio-Costet, M. 1997. A mutation in the $14 \alpha$-demethylase gene of Uncicula necator that correlates with resistance to a sterol biosynthesis inhibitor. Appl. Environ. Microbiol., 63, 2966-2970.

Djukic, D. and Mandic, L. 2000. Microorganisms and technogenic pollution of agroecosystem. Acta. Agricul. Serbica, 5(10): 3744

Domingues, F.C., Queiroz, J.A., Cabral, J.M. and Fonseca, L.P. 2000. The influence of culture conditions on mycelia structure and cellulase production by Trichoderma reesei Rut C-30. Enzyme and Microbial Technol., 26(5-6): 394-401.

Dulay, R.M.R., Pascual, A.H.L., Constante, R.D., Tiniola, R.C., Areglo, J.L., Arenas, M.C., Kalaw, S.P. and Reyes, R.G. 2015. Growth response and mycoremediation activity of Coprinus comatus on heavy metal contaminated media Mycosphere, 6 (1): $1-7$.

Ezzi, I.M. and Lynch, J.M. 2005. Biodegradation of cyanide by Trichoderma spp. and Fusarium spp. Enzyme Microbial Technol., 36: 849-954. doi:10.1016/j. enzmictec 2004.03.030.

Gaddeyya, G., P. Shiny Niharika, P. Bharathi and P. K. Ratna Kumar. 2012. Isolation and identification of soil mycoflora in different crop fields at Salur Mandal. $A d v$. Appl. Sci. Res., 3(4): 2020-2026.

Ganaie, M.A., S. Sood, G. Rizvi and T.A. Khan. 2010. Isolation and Identification of Keratinophilic Fungi from Different Soil Samples in Jhansi City (India. Plant Pathol. J., 9: 194-197.

Goldman, G., Temmerman, W., Jacobs, D.,
Contreras, R.,van Montagu, M. and Herrera-Estrella, A. 1993. A nucleotide substitution in one of the beta-tubulin genes of Trichoderma viride confers resistance to the antimitotic drug methyl benzimidazole 2-yl-carbamate. Mol. General Genetics, 240, 73-80.

Jahangeer, S., Khan, N., Jahangeer, S., Sohail, M., Shahzad, S., Ahmad, A. and Khan, S.K. 2005. Screening and characterization of fungal cellulases isolated from the native environmental source. Pak. J. Bot., 37(3): 739-748.

Kiran, S., Jaishree, B. and Sobha, V.A. 1999. Effect of thiram on root growth, root nodules and nitrogen fixation in Glycine max (L. merril by Brady rhizobium japonicum. J. Soil Biol. Ecol., 19: 11-14.

Kredics, L., Antal, Z., Manczinger, L., Szekeres, A., Kevei, F and Nagy E. 2003. Influence of environmental parameters on Trichoderma strains with biocontrol potential. Food Technol. Biotechnol., 41(1); 37-42.

Li, X., Yang, H., Roy, B., Park, E.Y., Jiang, L., Wang, D. and Miao, Y. 2010. Enhanced cellulase production of the Trichoderma viride mutated by microwave and ultraviolet. Microbiol. Res., 165(3): 190 198.

Luis Henerique, S.G., Simone, C.P.N., Michele, M., Ana, C.S.R., Valeria, C.S., Fabiana, F.Z., Ana Carla, M.M.A., Altino, B. 2010. Screening of filamentous fungi for the production of enzymes for biotechnological interest. Brazilian $J$. Microbiol., 37: 474-480.

Lynd, L.R., Weimer, P.J., van Zyl, W.H. and Pretorius, I.S. 2002. Microbial cellulose utilization: fundamentals and biotechnology. Microbiol. Mol. Biol. Rev., 66(3): 506-77.

Ma, Z. and Michailides, J. 2005. Advances in understanding molecular mechanisms of fungicide resistance and molecular detection of resistant genotypes in phytopathogenic fungi. Crop Protection, 24, 853-863. Doi:10.1016/j.cropro.2005. 01.011 . 
Mishra, N., Khan, S.S., Sundari, S.K. 2016. Native isolate of Trichoderma: a biocontrol agent with unique stress tolerance properties. World J. Microbiol. Biotechnol., 32(8):130. doi: 10.1007/s11274-016-2086-4. Epub 2016 Jun 23. Abstract).

Mukherjee, P.K., Sherkhane, P.D. and Murthy, N.B. 1999. Induction of stable benomyltolerant phenotypic mutants of Trichoderma pseudokoningii MTCC 3011, and their evaluation for antagonistic and biocontrol potential. Indian $J$. Experimental Biol., 37: 710- 712.

Oghenekaro, A.O., Okhuoya, J.A., Akpaja, E.O. 2008 - Growth of Pleurotus tuberregium (Fr. Singer on some heavy metalsupplemented substrates. African $J$. Microbiol. Res., 2: 261-271.

Orgiazzi, A., Lumini, E., Nilsson, R.H., Girlanda, M. and Vizzini, A. 2012. Unravelling Soil Fungal Communities from Different Mediterranean Land Use Backgrounds. PLoS ONE, 7(4): e34847.

Ruocco, M., Lanzuise, S., Vinale, F., Marra, R., Turrà, D., Woo, S.L. and Lorito, M. 2009. Identification of a new biocontrol gene in Trichoderma atroviride: The role of an $\mathrm{ABC}$ transporter membrane pump in the interaction with different plant-pathogenic fungi. Mol. Plant-Microbe Interactions, 22, 291-301.

Seth, R.K., S. Alam and Shukla, D.N. 2016. Isolation and identification of Soil Fungi from Wheat Cultivated Area of Uttar Pradesh. Plant Pathol. Microbiol., 7(11): 1-3.

Shearer, C.A., Descals, E., VolkmannKohlmeyer, B., Kohlmeyer, J., Marvanova, L., et al. 2007. Fungal biodiversity in aquatic habitats. Biodiversity and Conservation, 16: 49-67.
Tang, J., Liu, L., Hua, S., Chen, Y. and Chen, J. 2009. Improved degradation of organophosphate dichlorvos by Trichoderma atroviride transformants generated by restriction enzyme-mediated integration (REMI. Biores.e Technol., 100: 480-483.

doi:10.1016/j.biortech.2008.05.022.

Vadkertiova, R. and Slavikova, E. 2006. Metal tolerance of yeasts isolated from water, soil and plant environments. J. Basic Microbiol., 46: 145-152.

Volesky, B. 1990. Biosorption and biosorbents: In Biosorption of heavy metals. CRC Press, Florida, pp: 3.

Volesky, B. 1990. Biosorption and biosorbents. In:Biosorption of Heavy Metals. CRC Press, Boston.

Yamamoto, E. and Baird, V. 1999. Molecular characterization of four beta-tubulin genes from dinitroaniline susceptible and resistant biotypes of Eleusine indica. Plant Mol. Biol., 39: 45-61.

Yan, K. and Dickman, M. 1996. Isolation of a $\beta$ tubulin gene from Fusarium moniliforme that confers cold-sensitive benomyl resistance. Appl. Environ. Microbiol., 62: 3053- 3056.

Zhou, X., Xu, S., Liu, L. and Chen, J. 2007. Degradation of cyanide by Trichoderma mutants constructed by restriction enzyme mediated integration (REMI). Biores. Technol., 98: 2958-2962.

Zúñiga-Silva, J.R., Chan-Cupul, W. Loera, O., Aguilar-López, R. Xoconostle-Cázares, B. and Vázquez, R.R. 2016. In vitro toxic effects of heavy metals on fungal growth and phosphate-solubilising abilities of isolates obtained from Phragmites australis rhizosphere Chem. Ecol., 32(1): 49-67.

\section{How to cite this article:}

E.A. Ekundayo, F.C. Akharaiyi, F.O. Ekundayo, E. Prebor, O.T. Ogunmefun and Oluwafemi, Y. 2018. In vitro Interactions of Fungal Isolates obtained from Selected Soil Samples in Ado-Ekiti Metropolis and their Tolerance to Selected Fungicide and Heavy Metals. Int.J.Curr.Microbiol.App.Sci. 7(3): 3573-3585. doi: https://doi.org/10.20546/ijcmas.2018.703.411 